\title{
Composition of Smectite from Maastrichtian Sediment of the Afikpo Basin, Southeast Nigeria
}

\author{
${ }^{1}$ AGIBE, AN; *1UZOEGBU, MU; ${ }^{2}$ NDUKWE, OS; ${ }^{2}$ NDUKWE, VA
}

\author{
${ }^{1}$ Department of Geology, Federal University, Oye-Ekiti, Ekiti State, Nigeria. \\ ${ }^{2}$ Department of Geology, University of Port Harcourt, Port Harcourt, Nigeria. \\ *Corresponding Author Email: uche.uzoegbu@uniport.edu.ng; Tel: 08030715958
}

\begin{abstract}
The sand, silt, shale and clay fractions soils derived from Maastrichtian sediments in the Afikpo Basin, southeastern Nigeria exhibit unusually high cation-exchange capacities. Smectite was identified by X-ray diffraction in all sample fractions and was selectively dissolved by treatment with $1 \mathrm{HCl}$ and $0.5 \mathrm{NaOH}$. Structural formulae, based on chemical analysis of the dissolved material, suggest that the smectite is intermediate in composition between a di- and a trioctahedral mineral and that the octahedral cation occupancy, together with the number of $\mathrm{Mg}$ and $\mathrm{Fe}$ atoms per unit cell, decreases with decrease in particle size of the soil fraction examined. The mean formula for the smectite in the clay separate is: $\left[\left(\mathrm{M}^{+}=0.40, \mathrm{Si}=3.33, \mathrm{Al}=0.67\right),\left(\mathrm{Al}=1.07, \mathrm{Fe}^{2+}=0.09, \mathrm{Fe}^{3+}=0.41, \mathrm{Mg}=0.82\right)\right] \mathrm{O}_{10}(\mathrm{OH})_{2}$. Similar analysis of smectite present in clay-size material separate from weathered granitic rock taken from the bases of the soilprofiles showed that it had close to the full trioctahedral inherited from the weathered granites. The clay mineralogy of the soils was affected by inherited smectite, probably of hydrothermal of deuteric origin. This mineral is unstable in the soil environment and, although its alteration products are fairly uniform in composition.
\end{abstract}

\section{DOI:https://dx.doi.org/10.4314/jasem.v23i8.24}

Copyright: Copyright $\left({ }^{C} 2019\right.$ Agibe et al. This is an open access article distributed under the Creative Commons Attribution License (CCL), which permits unrestricted use, distribution, and reproduction in any medium, provided the original work is properly cited.

Dates: Received: 25 July 2019; Revised: 13 August 2019; 20 August 2019

Keywords: Dissolution, Granitic, Octahedral, Smectite, Soil.

The study area falls within latitude $5^{\circ} 20^{\prime}$ to $6^{\circ} 00^{\prime} \mathrm{N}$ and longitude $7^{\circ} 40^{\prime}$ to $7^{\circ} 60^{\prime} \mathrm{E}$ (Fig. 1). This region constitutes part of southern extension in Anambra Basin, referred to as Afikpo sub-basin. It is situated within Okigwe - Afikpo areas of southeastern Nigeria. The Maastrichtian sediment in the Afikpo Basin form part of the Nsukka Formation. Accessibility to the study area is through the Port-harcourt - Enugu express way, via Umuahia - Bende to Ohafia - and Okigwe - Amaseri to Afikpo (Fig. 1). An access route to the study area also includes - a network of major, secondary, minor roads and footpaths which help in interconnecting the inhabitants of these areas. Clay mineral compositions in shallow marine and deep marine environments are largely controlled by detrital clay derived from the continents. Also the mineralogical composition of clay minerals depends on the environment of deposition (Porrenga, 1967). Therefore, they can be used in determining the depositional environments of sediments (Mamman et al., 2010).Research has shown that clays in open marine environment contains mainly of illites, montmorillonite and chlorites with illites and chlorites increasing seawards and kaolinites decreasing seawards (Keller, 1970). Diagenetical processes of clay minerals based on grain sizes under marine conditions shows that clay mineral grain decreases with depth offshore as a result of water current (Porrenga, 1967), therefore kaolinite will be associated with continental to shallow marine environments while montmorillonite, illites and chlorites will suggest deposition in outer shelf (deep marine) environment. Indeed, clay minerals are used widely for different scientific purposes such as interpreting and understanding such problems as tectonics, provenance, facies, boundaries, correlation, zonation, age, metamorphism, oil exploration with its latest application in paleoclimate determination. According to (Churchman, 2000), the two-layer/threelayer clay mineral ratio is mainly controlled by climate. Therefore, it is easy to recognize between warm and humid conditions typical for kaolinite or halloysite formation, or dry seasons, specific for illite or smectite formation. Furthermore, the formation of kaolinite and halloysite is favored by an acidic $(\mathrm{pH} \sim 3)$ conditions, and high leaching environments. Conversely, relatively low or no leaching environment and conditions under neutral to medium alkaline $\mathrm{pH}$ favor the formation of smectite and three layer clay minerals. The research aims in evaluating the composition and source of smectite in the 
Maastrichtian sediments of the Afikpo Basin vis-à-vis the Nsukka Formation.

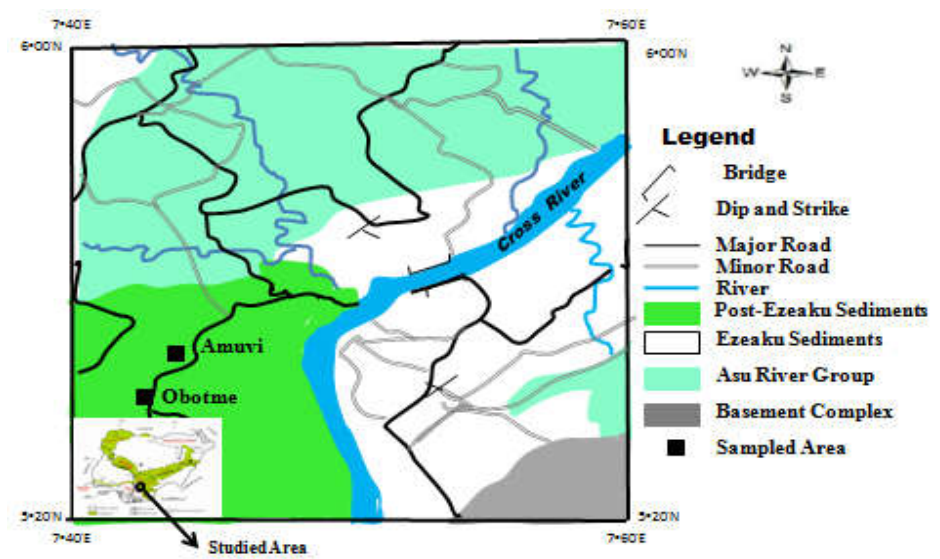

Fig. 1: Geology of Afikpo sub-Basin and study locations (after Omontese et al., 2019).

Stratigraphic Setting: The Santonian deformational process resulted in the fragmentation of the lower Benue trough (Table 1) into the Abakiliki syncline (Kogbe, 1976). The predominantly AlbianCenomanian marine depositional cycles which terminated by a phase of folding (Olade, 1975; Nwachukwu, 1972) affected the Asu River Group in the area.A second transgressive - regressive of deposition in the Turonian to Santonian was again terminated by a phase of folding and faulting in the early Santonian times which affected all the sediments deposited before the tectonism and this gave rise to the Afikpo (Abakiliki) syncline (Table 1). The Afikpo
Basin is part of the Southern Benue Trough, an Inland intra-continental sedimentary basin originating from the lower Benue Trough (Obaje et al., 2004) with NESW trending towards the Niger Delta. According to Kulke (1995), petroleum exploration in this basin was provoked as a result of existence of surface seeps dating back to the early 1930 s. Nevertheless, due to the Santonian inversion and prevalence of continental sediments, including discoveries in the prolific NigerDelta, the exploration and exploitation for petroleum has been ongoing in this area (Doust and Omatsola, 1990; Ekweozor and Gormly, 1983; Haack et al., 2000; Ugwueze, 2015).

Table 1: Stratigraphic units of the lower Benue trough.

\begin{tabular}{|c|c|c|c|c|}
\hline \multicolumn{2}{|r|}{ Age } & Anambra Basin & Afikpo Basin & Calabar Basin \\
\hline \multirow{10}{*}{ Tertiary } & Oligocene & Ogwasi-Asaba Fm & Ogwasi-Asaba Fm & \\
\hline & Eocene & Amki Group & Amki Group & \\
\hline & Paleocene & Imo Shale & Imo Shale & \\
\hline & & Nsukka Formation & Nsukka Formation & \\
\hline & Maastricthtian & Ajali sandstone & Ajali sandstone & \\
\hline & & Manu shale & Manu shale Nkporo shale & \\
\hline & Campanian & Nkporo shale & Enugu shale & Nkporo shale \\
\hline & & Enugu shale & Afikpo sandstones & \\
\hline & Santonian & & & \\
\hline & Coniacian & Agwu shale & Agwu shale & \\
\hline \multirow[t]{4}{*}{ Cretaceous } & Turonia & Eze-Aku Group & Eze-Aku Group & New Netim Marl \\
\hline & Cenomanian & & & Ekenkpon Shales \\
\hline & Albian & & Asu River group & M farmosing Limestone \\
\hline & Aptian & & & Awi Foundation \\
\hline Precambrian & \multicolumn{4}{|c|}{ Basement complex } \\
\hline
\end{tabular}

The first marine transgression in Nigeria occurred during the middle Albian. Albian sediments not mentioned and unvarying comprise Asu River Group and its equivalents (Ojoh, 1990). Ukaegbu and Akpabio (2009) have differentiated the Albian sediments, northeast Afikpo Basin as consisting of alternating shale, siltstone with occurrence of sandstone, maximum thickness of $1000 \mathrm{~m}$ rich in ammonites as well as foraminifera, radiolarian and pollens. Also present in the shales are traces of elobiceras and monticeras ammonites (Ojoh, 1999).

\section{MATERIAL AND METHODS}

Collection of Samples: The shale and clay samples from hand dug wells were derived from Maastrichtian sediment at Amuvi and Obotme from the Nsukka 
Formation in the Afikpo Basin, southeast Nigeria, were analyzed. The Amuvi (AMU) sample showed some mottling in the AMU3 indicative of drainage impedence, whereas Obotme(OBO) samples appeared to be freely drained. Some properties of these soils are given in Table 2. Sand, silt and clay fractions were separated by the usual sieving and sedimentation procedures following dispersion of the soils using a Rapidis 150 ultrasonic vibrator, according to method of Genrich and Bremner (1972).

Sample Treatment and Preparation: After destruction of organic matter $(\mathrm{OM})$ by $\mathrm{H}_{2} \mathrm{O}_{2}$ treatment, the separates were $\mathrm{Ca}$-saturated, washed free of excess salt, and dried. Clay samples were also separated from fragments of weathered granitic by first crushing them in a mortar and then dispersing them ultrasonically. Free $\mathrm{Fe}$ and $\mathrm{Al}$ in the size fractions were extracted using dithionite-citrate-bicarbonate (DCN) (Mehra and Jackson, 1960). Noncrystalline material was dissolved by boiling DCB-treated samples in 0.5 $\mathrm{NaOH}$ (Hashimoto and Jackson, 1960). The Fe released by this treatment was extracted by an additional DCB treatment. A cation-exchange capacity (CEC) was determined on deferrated, $\mathrm{NaOH}$ treated samples using a $\mathrm{BaCl}_{2}$ solution buffered at $\mathrm{pH}$ 8.2 with triethanolamine. Potassium fixation was estimated by the method of Alexiades and Jackson (1965). Removal of interlayer Al was attempted on selected samples using the sequential sodium citrate extraction procedure of Frink (1965).

X-ray powder diffraction (XRD) analysis was carried out ondeferrated, $\mathrm{NaOH}$-treated samples of sands, silts and clay using a Philips X-ray diffractometer and Nifiltered $\mathrm{CuK} \alpha$ Radiation at $40 \mathrm{kV}$ and $20 \mathrm{ma}$. Identification of the clay minerals was based on the basal reflection patterns on the diffractograms (Figs 2 and 3).

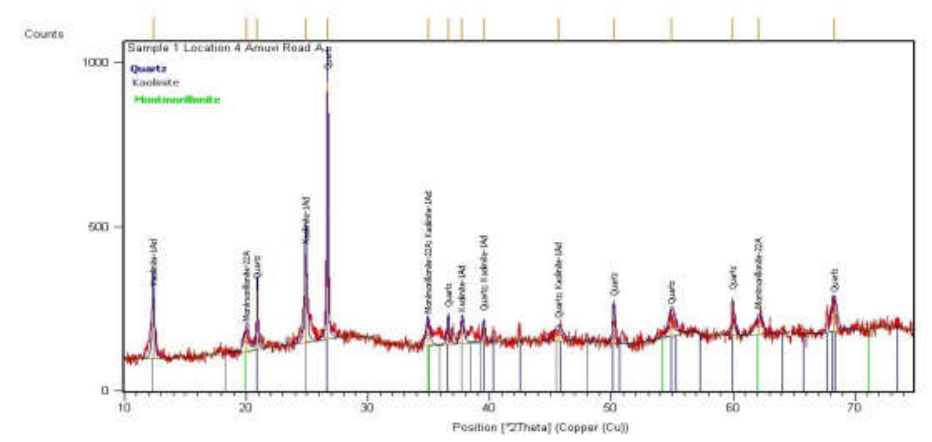

Fig. 2: XRD pattern for Amuvi sample in the Nsukka Formation.

The sands were prepared as random powders, whereas the silts were sedimented onto glass slides. The clays were divided into coarse $(2-0.2 \mu \mathrm{m})$ and fine $(<0.2$ $\mu \mathrm{m})$ fractions by centrifugation. Subsamples were saturated with $\mathrm{K}^{+}$, pipette onto glass slides, and air dried. The K-saturated samples were also heated at $300^{\circ}$ and $550^{\circ} \mathrm{C}$ in a muffle furnace for 2 hours. A Mgglycerol samples was prepared by suspending a $\mathrm{Mg}$ saturated samples in $1 \mathrm{ml}$ of $10 \%$ glycerol in water. Differential thermal analysis (DTA) was performed on samples clay $(<0.2 \mu \mathrm{m}$, Ca-saturated), equilibrated for at least 4 days in a desiccator over a saturated $\mathrm{Mg}\left(\mathrm{NO}_{3}\right)_{2}$ solution, using a Stanton-Redcroft 673-4 instrument at a heating rate of $20^{\circ} \mathrm{C} / \mathrm{min}$ in a nitrogen atmosphere. $\mathrm{Al}_{2} \mathrm{O}_{3}$ was used as reference. Acid dissolution of samples, previously treated with DCB and $\mathrm{NaOH}$ to remove free oxides and amorphous silicates, was carried out by digesting $100 \mathrm{mg}$ of sample (Ba-saturated) in $50 \mathrm{ml}$ of $1 \mathrm{HCl}$ on a water bath at $80^{\circ} \mathrm{C}$ for $24 \mathrm{hr}$.

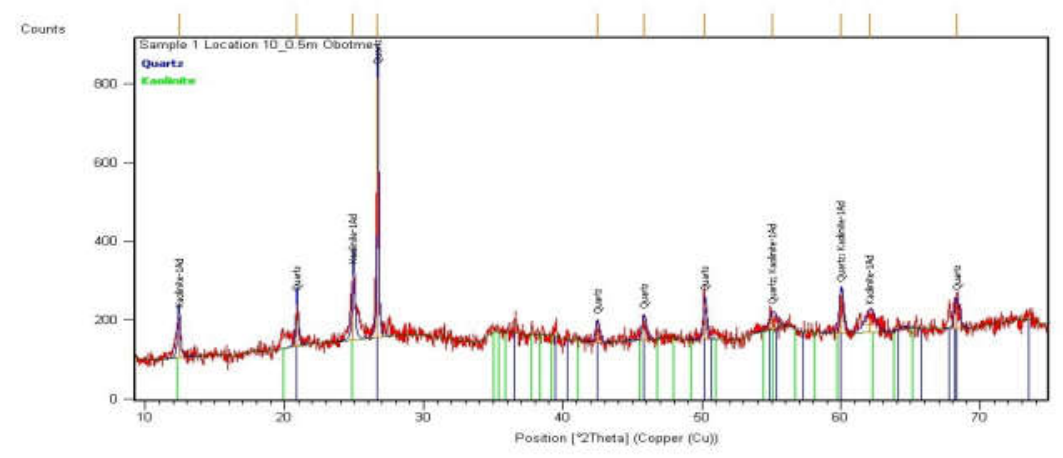

Fig. 3: XRD pattern for Obotme sample in the Nsukka Formation. 
The residue was washed with $25 \mathrm{ml}$ of $1 \mathrm{HCl}$. The wash solutions were combined with the supernatants and brought up to volume. The residue were treated with boiling $0.5 \mathrm{NaOH}$ for $2.5 \mathrm{~min}$. Si and $\mathrm{Fe}^{2+}$ in the extracts were determined colorimetrically (Pruden and King, 1969). $\mathrm{Al}$, total $\mathrm{Fe}, \mathrm{Mg}, \mathrm{Ca}, \mathrm{K}$ and $\mathrm{Na}$ were determined by atomic absorption spectroscopy. The effect of time on acid dissolution of selected silts was assessed by subjecting the samples to acid treatment from 2 to $30 \mathrm{hr}$. The residues were boiled in $0.5 \mathrm{NaOH}$ as before.

Data Analysis: Results were presented as peak positions at $2 \theta$ and $x$-ray counts in the form of a table or an $\mathrm{x}-\mathrm{y}$ plot. Intensity $(I)$ is reported as peak height intensity (intensity above background). The relative intensity is recorded as the ratio of the absolute intensity of every peak to the absolute intensity of the most intense peak, and then converts to a percentage.

\section{RESULT AND DISCUSSION}

Table 2 shows some properties of soils containing smectite from samples collected from the area. The results obtained from unheated, air dried and unglycolated soil samples shows that the bulk mineral composition of the sand, silt and clay from Nsukka Formations as in the table 1below comprises of quartz, clay minerals, carbonates, iron rich minerals such as hematite, etc. Kaolinite is the major clay mineral present in the formation with minor amounts of illite and smectite (Onyeogu et al., 2016).

Dissolution of Smectite: Calculation of smectite composition by applying corrections for the other minerals present was successfully employed by Sawhney and Jackson (1958) and Mackenzie (1960). The low temperature of smectite dehydroxylation in the study clays precluded quantitative determination of kaolinite by DTA or by the dissolution procedure of Hashimoto and Jackson (1960).

Table 2: Some properties of the soils containing smectite.

\begin{tabular}{|c|c|c|c|c|c|c|c|c|}
\hline $\begin{array}{l}\text { Sample } \\
\text { Location }\end{array}$ & $\begin{array}{l}\text { Depth } \\
\text { (cm) }\end{array}$ & pH & $\begin{array}{l}\text { CEC } \\
(\mathrm{meq} / 100 \mathrm{~g})\end{array}$ & $\begin{array}{l}\text { Base } \\
\text { Saturation (\%) }\end{array}$ & $\begin{array}{l}\text { Organic } \\
\text { Matter (\%) }\end{array}$ & $\begin{array}{l}\text { Sand }^{2} \\
(\%)\end{array}$ & $\begin{array}{l}\text { Silt } \\
(\%)\end{array}$ & $\begin{array}{l}\text { Clay } \\
(\%)\end{array}$ \\
\hline \multicolumn{9}{|l|}{ Amuv $^{1}$} \\
\hline AMU1 & 20.00 & 6.13 & 58.30 & 52.60 & 9.25 & $21.80(38.40)$ & $43.90(36.10)$ & $35.30(60.50)$ \\
\hline AMU2 & 15.00 & 5.56 & 53.00 & 39.50 & 5.61 & $17.30(36.00)$ & $42.60(34.20)$ & $41.10(63.10)$ \\
\hline AMU3 & 30.00 & 5.78 & 54.30 & 18.30 & 4.15 & $22.30(55.50)$ & $55.70(46.00)$ & $22.00(67.30)$ \\
\hline AMU4 & 45.00 & 5.92 & 54.70 & 64.20 & 1.00 & $51.50(54.87)$ & $51.50(46.80)$ & $27.70(65.70)$ \\
\hline \multicolumn{9}{|l|}{ Obotme $^{1}$} \\
\hline OBO1 & 20.00 & 6.00 & 62.90 & 36.40 & 10.51 & $19.80(35.90)$ & $48.30(40.70)$ & $31.90(64.30)$ \\
\hline $\mathrm{OBO} 2$ & 15.00 & 5.62 & 60.40 & 25.30 & 8.88 & $18.40(36.70)$ & $46.30(40.30)$ & $35.30(67.30)$ \\
\hline OBO3 & 30.00 & 5.70 & 57.60 & 16.10 & 5.35 & $26.40(47.00)$ & $49.90(41.60)$ & $23.70(71.60)$ \\
\hline OBO4 & 45.00 & 5.55 & 54.70 & 44.50 & 0.98 & $18.10(54.70)$ & $46.80(56.70)$ & $35.10(69.90)$ \\
\hline
\end{tabular}

Acid treatments have been used for the selective dissolution of chlorite (Brindley, 1961) and vermiculite (Ristori et al., 1974). The partial dissolution of smectite at low $\mathrm{pH}$ during CEC determinations (Curtin, 1979; Freed and Peacor, 1989) suggested that smectite might be selectively dissolved using dilute acid. The smectite was completely dissolved by an acid dissolution procedure similar to that of Ristori et al. (1974). The residues consisted of kaolinite, mica and quartz with a trace of feldspar in the clay separates, whereas quartz, augite and feldspar remained in the silt and sand separates (Figs 2 and 3).Chemical analyses of the $\mathrm{HCl}$ and $\mathrm{NaOH}$ extracts of the sand, silt and clay separate from the Obotme samples are given in Table 3. The data for the Amuvi samples are similar and are not presented. Most of the clay fraction was dissolved by the treatment. The solubility of pure kaolinite and the amount of $\mathrm{K}$ in the $\mathrm{HCl}$ extracts (Table 3 ) indicate that the nonsmectite mineral in the clay fraction were partially dissolved by the treatment. However, the intensities of the kaolinite, mica and quartz diffraction peaks were much increased by the treatment, showing that substantial concentration of these minerals had occurred. Because the initial amount of kaolinite, mica and quartz in the clay separates was low (e.g $\mathrm{K}_{2} \mathrm{O}=0.22-0.80 \%$ ). It is unlikely that the partial dissolution of these minerals led to a significant error in the calculation of smectite composition. The solubility of the silt and sand fractions was lower than that of the clay fractions. The alteration of the nonsmectite minerals in the $>2 \mu \mathrm{m}$ fraction was assessed by subjecting silt samples, which had been pretreated with $\mathrm{DCB}$ and $\mathrm{NaOH}$, to acid treatment for $2-30 \mathrm{hr}$. Typical dissolution data are presented in Figure 4. HCl-soluble $\mathrm{Mg}$ showed little increase after $2 \mathrm{hr}$ of acid treatment. The amount of Fe extracted increased substantially between 2 and $8 \mathrm{hr}$, but longer extraction periods removed little additional iron. Although $\mathrm{Al}$ extracted by $\mathrm{HCl}$ also increased substantially between 2 and $8 \mathrm{hr}$, subsequent increases were relatively small. The amount of $\mathrm{Al}$ dissolved by the $2.5 \mathrm{~min} \mathrm{NaOH}$-boiling treatment decreased as the duration of the acid dissolution increased. The amount of $\mathrm{Si}$ dissolved by the two 
reagents paralleled fairly closely the total $\mathrm{Al}$ dissolution data. The fact that little or no increase with time was noted for $\mathrm{Mg}$ suggests that augite, which has a high $\mathrm{Mg}$ content, was not being attacked by the acid. Some dissolution of feldspar occurred as indicated by the presence of $\mathrm{ca}, \mathrm{Na}$ and $\mathrm{K}$ in the $\mathrm{HCl}$ extracts (Table 3). Plagioclase feldspars are increasingly susceptible to acid attack as $\mathrm{Ca}$ content increases (Curtin and Smillie, 1981). However, an average of only $12.5 \%$ of the total $\mathrm{Ca}$ in the sands and silts was dissolved by $\mathrm{HCl}$, indicating a limited dissolution of feldspar. The results of Kiely and Jackson (1965) suggest that siltand sand-sized quartz should be little affected by this treatment. These patterns of dissolution are consistent with the conclusions of Grim (1968) that alkaline earth cations are removed more rapidly during acid attack on smecitite than are $\mathrm{Al}$ or $\mathrm{Fe}$ and that $\mathrm{Fe}$ is removed more rapidly than Al. Avery high correlation coefficient of $\mathrm{r}=0.98$ was found between $\mathrm{CEC}$ and the sum of the oxides $\left(\mathrm{SiO}_{2}+\mathrm{Al}_{2} \mathrm{O}_{3}+\mathrm{FeO}+\mathrm{Fe}_{2} \mathrm{O}_{3}+\right.$
$\mathrm{MgO}$ ) dissolved by $\mathrm{HCl}$ and $\mathrm{NaOH}$. This relationship may indicate that the dissolution procedure was highly selective for the smectite. Extrapolation of the relationship between $\mathrm{CEC}$ and total dissolved oxides indicates that the mineral has a CEC of about 100 meq/100 g.Although the dissolution procedure was highly selective for smectite, ratios of the dissolved oxides were not constant, but varied substantially with particle size. In general, with decreasing particle size, $\mathrm{Mg}$ and $\mathrm{Fe}$ decreased relative to both $\mathrm{Al}$ and $\mathrm{Si}$. The $\mathrm{Si} / \mathrm{Al}$ ratio also decreased with decreasing particle size. Structural formulae (Table 4), based on the amount of $\mathrm{Si}, \mathrm{Al}, \mathrm{Mg}, \mathrm{Fe}^{3+}$ and $\mathrm{Fe}^{2+}$ dissolved by $\mathrm{HCl}$ and $\mathrm{NaOH}$ and on the CEC values, were calculated according to the procedure of Marshall (1949). The tetrahedral sheet was relatively constant in composition and had a high negative charge. Six of the eight samples analyzed were in the relatively narrow range $\mathrm{Si}$ (3.30) $\mathrm{Al}(0.7)$ - $\mathrm{Si}$ (3.5) $\mathrm{Al}(0.5)$.

Table 3: Elements dissolved from Obotme samples by the $1 \mathrm{HCl}$ and $0.5 \mathrm{NaOH}$ treatments (\% of oven-dried samples.

\begin{tabular}{|c|c|c|c|c|c|c|c|c|c|c|c|}
\hline $\begin{array}{l}\text { Sample } \\
\text { Location }\end{array}$ & $\begin{array}{l}\mathrm{SiO}_{2} \\
(\mathrm{HCI}) \\
(\%)\end{array}$ & $\begin{array}{l}\mathrm{Al}_{2} \mathrm{O}_{3} \\
(\mathrm{HCl}) \\
(\%)\end{array}$ & $\begin{array}{l}\text { MgO } \\
\text { (\%) }\end{array}$ & $\begin{array}{l}\mathrm{FeO} \\
(\%)\end{array}$ & $\begin{array}{l}\mathrm{Fe}_{2} \mathrm{O}_{3} \\
(\%)\end{array}$ & $\begin{array}{l}\mathrm{CaO} \\
\text { (\%) }\end{array}$ & $\begin{array}{l}\mathrm{Na}_{2} \mathrm{O} \\
(\%)\end{array}$ & $\begin{array}{l}\mathrm{K}_{2} \mathrm{O} \\
(\%)\end{array}$ & $\begin{array}{l}\mathrm{SiO}_{2} \\
(\mathrm{NaOH}) \\
(\%)\end{array}$ & $\begin{array}{l}\mathrm{Al}_{2} \mathrm{O}_{3} \\
(\mathrm{NaOH}) \\
(\%)\end{array}$ & $\begin{array}{l}\text { Total } \\
(\%)\end{array}$ \\
\hline \multicolumn{12}{|c|}{ Sand fraction } \\
\hline OBO1 & 12.08 & 7.76 & 4.59 & 1.31 & 4.74 & 0.56 & 0.18 & 0.05 & 10.08 & 0.27 & 41.62 \\
\hline $\mathrm{OBO} 2$ & 12.42 & 7.59 & 4.66 & 1.24 & 5.06 & 0.55 & 0.15 & 0.05 & 9.58 & 0.27 & 41.57 \\
\hline OBO3 & 12.42 & 8.61 & 6.37 & 1.44 & 6.33 & 0.44 & 0.08 & 0.15 & 12.50 & 0.27 & 48.61 \\
\hline OBO4 & 11.75 & 7.99 & 8.84 & 1.69 & 6.89 & 0.29 & 0.05 & 0.05 & 14.80 & 0.27 & 52.62 \\
\hline \multicolumn{12}{|c|}{ Silt fraction } \\
\hline OBO1 & 12.63 & 8.28 & 3.40 & 0.89 & 4.20 & 0.38 & 0.15 & 0.07 & 10.19 & 0.38 & 40.57 \\
\hline $\mathrm{OBO} 2$ & 12.50 & 8.13 & 3.55 & 0.88 & 4.21 & 0.42 & 0.13 & 0.09 & 9.88 & 0.34 & 40.13 \\
\hline OBO3 & 12.78 & 8.59 & 4.31 & 1.07 & 5.03 & 0.23 & 0.11 & 0.22 & 10.38 & 0.34 & 43.06 \\
\hline OBO4 & 13.31 & 11.5 & 5.91 & 0.89 & 6.44 & 0.35 & 0.08 & 0.07 & 16.88 & 0.54 & 55.58 \\
\hline \multicolumn{12}{|c|}{ Clay fraction } \\
\hline OBO1 & 13.60 & 14.94 & 5.31 & 1.25 & 5.79 & nd & 0.07 & 0.14 & 21.92 & 0.57 & 63.59 \\
\hline $\mathrm{OBO} 2$ & 13.33 & 14.40 & 5.47 & 1.58 & 5.53 & nd & 0.06 & 0.16 & 21.43 & 0.72 & 62.68 \\
\hline OBO3 & 14.60 & 14.31 & 6.63 & 1.27 & 5.78 & nd & 0.08 & 0.27 & 19.96 & 0.61 & 63.51 \\
\hline OBO4 & 12.67 & 16.20 & 6.05 & 0.81 & 5.56 & nd & 0.07 & 0.12 & 26.30 & 0.91 & 68.73 \\
\hline \multicolumn{12}{|l|}{ Kaolinite } \\
\hline$(<2 \mu \mathrm{m})$ & 3.74 & 2.74 & - & - & - & - & - & - & 3.27 & 2.05 & - \\
\hline
\end{tabular}

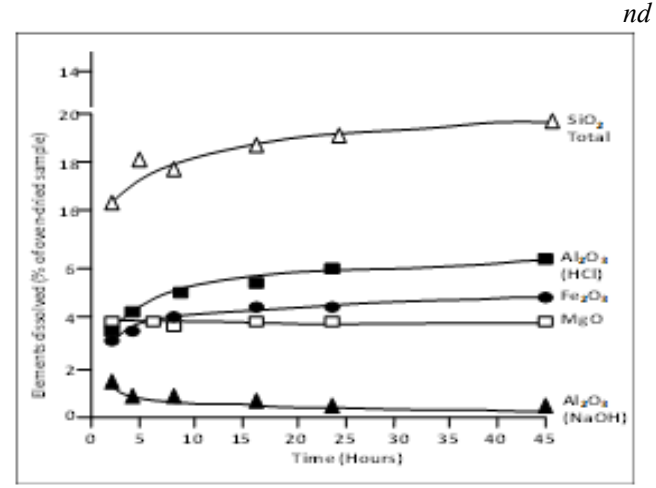

Fig. 4: Effect of duration of treatment with $1 \mathrm{HCl}$ on the amounts of $\mathrm{SiO}_{2}, \mathrm{Al}_{2} \mathrm{O}_{3}, \mathrm{Fe}_{2} \mathrm{O}_{3}$ and $\mathrm{MgO}$ dissolved from the silt fraction AMU 2 (after Curtin and Smillie, 1981).

The remaining samples contained slightly more tetrahedral Al. Much of the tetrahedral charge is neutralized by the positively charged octahedral sheet. The tetrahedral origin of the negative charge may account for the ability of these samples to fix small amounts of K (Table 5) and for the fact that they expand with some difficulty. The composition of the octahedral sheet is apparently about midway between that of a dioctahedral and trioctahedral mineral, but the number of octahedral cations per half unit cell apparently decreases with a decrease in the particle size of the initial separate (Curtin and Smillie, 1981). Octahedral $\mathrm{Al}$ increases, whereas $\mathrm{Mg}$, and to a lesser extent Fe decreases, with decrease in particle size. The calculated formulae are consistent with the finding of McAleese (1954) that heating Li-saturated silts and clays of similar origin to $200^{\circ} \mathrm{C}$ resulted in only marginal decreases in CEC, thereby excluding the possibility of the smectite being a dioctahedral mineral 
with predominantly octahedral substitution. The Increase in the calculated number of octahedral $\mathrm{Al}$ atoms per unit cell as particle size decreased could be due to an increase in the number of hydroxyl-Al interlayers. The assignment of $\mathrm{Al}$ from this source to smectite structure was suggested by Sawhney and Jackson (1958) as an explanation for montmorillonite formulae with high octahedral occupancies. The present formulae were calculated for samples which had been given a $\mathrm{NaOH}$ and two DCB treatments, a sequence which would be expected to remove much of the interlayer Al (Curtin and Smillie, 1981; Onyeogu et al., 2016). Most methods for selective removal of hydroxyl-Al interlayers cannot be used with the present samples because of the composition of the smectite. The procedure of Dixon and Jackson (1959) involves heating samples at $400^{\circ} \mathrm{C}$ followed by the dissolution of the dehydroxylated interlayer material in hot $\mathrm{NaOH}$. However, when this method was employed, large amounts of both $\mathrm{Si}$ and $\mathrm{Al}$ were removed, indicating that some dehydroxlyation of smectite had taken place even at this low temperature. Procedures involving the use of acid (Jan et al., 2002; Rich, 1966) obviously cannot be used because of the solubility of the smectite. The less severe procedure of
Frink (1965), which involves repeated extraction with 1 mole sodium citrate on a water bath at $80^{\circ}-90^{\circ} \mathrm{C}$, was tried on selected samples. The total amount of $\mathrm{Al}$ removed in eight, hour-long extractions was quite small (Table 6). The pattern of its extraction with time and its ratio with extracted $\mathrm{Fe}$ is indicative of attack on the smectite structure. It is concluded from these results that little interlayer $\mathrm{Al}$ was present in $\mathrm{NaOH}-$ treated clays.

Composition of smectite in granitic fragments: Although an average octahedral cation occupancy of 2.4 per $\mathrm{O}_{10}(\mathrm{OH})_{2}$ was estimated from the chemical data, the above clays gave a weak 060 reflection at $1.54 \AA$, indicating that the smectite has a the structure of a trioctahedral mineral (Curtin and Smillie, 1981). Smectite was also present in fine and coarse clays separated from weathered granitic fragments. The XRD data (Fig. 3) showed that it also had a more ordered structure that the smectite in the soil samples. It is because the chemical composition of the soil smectite varied considerably with particle size, and hence degree of weathering, the composition of the smectite may represent that of the original mineral.

Table 4: Structural formulae for smectite in size fractions of Amuvi and Obotme soils and in clays separated from granitic rock $^{1}$ (after Curtin and Smillie, 1981).

\begin{tabular}{|c|c|c|c|c|c|c|c|c|}
\hline & $\begin{array}{l}\text { Sand } \\
\text { Mean }\end{array}$ & $\begin{array}{l}\text { Fraction } \\
\text { Range }\end{array}$ & $\begin{array}{l}\text { Silt } \\
\text { Mean }\end{array}$ & $\begin{array}{l}\text { Fraction } \\
\text { Range }\end{array}$ & $\begin{array}{l}\text { Clay } \\
\text { Mean }\end{array}$ & $\begin{array}{l}\text { Fraction } \\
\text { Range }\end{array}$ & $\begin{array}{l}\text { Granitic } \\
\text { Fine }\end{array}$ & $\begin{array}{l}\text { Clays } \\
\text { Coarse }\end{array}$ \\
\hline \multicolumn{9}{|l|}{ Tetrahedral } \\
\hline $\mathrm{Si}$ & 3.32 & $3.19-3.42$ & 3.40 & $3.31-3.50$ & 0.33 & $3.22-3.40$ & 3.30 & 3.38 \\
\hline $\mathrm{Al}$ & 0.68 & $0.58-0.81$ & 0.60 & $0.50-0.69$ & 0.67 & $0.60-0.78$ & 0.70 & 0.62 \\
\hline \multicolumn{9}{|l|}{ Octahedral } \\
\hline $\mathrm{Al}$ & 0.66 & $0.36-0.83$ & 0.90 & $0.81-0.99$ & 1.07 & $0.96-1.20$ & 0.28 & 0.58 \\
\hline $\mathrm{Fe}^{2+}$ & 0.15 & $0.09-0.17$ & 0.11 & $0.08-0.13$ & 0.09 & $0.06-0.13$ & 0.46 & 0.78 \\
\hline $\mathrm{Fe}^{3+}$ & 0.57 & $0.51-0.62$ & 0.50 & $0.43-0.55$ & 0.41 & $0.36-0.43$ & 0.42 & 0.02 \\
\hline $\mathrm{Mg}$ & 1.17 & $0.92-1.58$ & 0.90 & $0.79-1.03$ & 0.82 & $0.67-1.01$ & 1.65 & 1.45 \\
\hline Total & 2.54 & $2.39-2.73$ & 2.41 & $2.35-2.46$ & 2.39 & $2.32-2.50$ & 2.81 & 2.83 \\
\hline Layer Charge & 0.37 & $0.37-0.42$ & 0.37 & $0.33-0.41$ & 0.40 & $0.37-0.42$ & 0.38 & 0.36 \\
\hline
\end{tabular}

Table 5: Potassium fixation by deferrated clays and silts (after Curtin and Smillie, 1981

\begin{tabular}{|c|c|c|c|}
\hline & $\begin{array}{l}\text { CEC } \\
(\mathrm{Ca} / \mathrm{Mg}) 1 \\
(\mathrm{meq} / \mathbf{1 0 0 g})\end{array}$ & $\begin{array}{l}\text { CEC } \\
\text { (K/NH4)2 } \\
\text { (meq/100g) }\end{array}$ & $\begin{array}{l}\text { K fixed } \\
\text { (meq/100g) }\end{array}$ \\
\hline Clay fraction & & & \\
\hline AMU1 & 57.40 & 43.80 & 13.60 \\
\hline AMU2 & 55.60 & 45.10 & 10.50 \\
\hline OBO1 & 61.40 & 48.10 & 13.30 \\
\hline $\mathrm{OBO} 2$ & 63.10 & 48.80 & 14.30 \\
\hline OBO3 & 56.40 & 47.40 & 9.00 \\
\hline OBO4 & 62.40 & 50.30 & 12.10 \\
\hline Silt fraction & & & \\
\hline OBO3 & 34.90 & 33.30 & 1.60 \\
\hline OBO4 & 53.60 & 45.30 & 8.30 \\
\hline
\end{tabular}

Table 6: Aluminum and iron in sodium citrate $\left(\mathrm{Na}_{3} \mathrm{C}_{6} \mathrm{H}_{5} \mathrm{O}_{7}\right)$ extracts of deferrated NaOH-treated clays (after Curtin and Smillie, 1981).

\begin{tabular}{lllll}
\hline & $\mathrm{Amuvi}$ & $(\mathrm{AMU1})$ & $\mathrm{Amuvi}$ & $((\mathrm{AMU} / 4)$ \\
& $\mathrm{Al}_{2} \mathrm{O}_{3}$ & $\mathrm{Fe}_{2} \mathrm{O}_{3}$ & $\mathrm{Al}_{2} \mathrm{O}_{3}$ & $\mathrm{Fe}_{2} \mathrm{O}_{3}$ \\
Extract & $(\%)$ & $(\%)$ & $(\%)$ & $(\%)$ \\
\hline
\end{tabular}




\begin{tabular}{lllll}
\hline 1 & 0.06 & 0.16 & 0.06 & 0.16 \\
2 & 0.07 & 0.15 & 0.08 & 0.13 \\
3 & 0.07 & 0.09 & 0.09 & 0.06 \\
4 & 0.07 & 0.06 & 0.07 & 0.05 \\
5 & 0.08 & 0.07 & 0.07 & 0.03 \\
6 & 0.05 & 0.04 & 0.03 & 0.03 \\
7 & 0.05 & 0.04 & 0.03 & 0.03 \\
8 & 0.05 & 0.04 & 0.03 & 0.03 \\
Total & 0.50 & 0.65 & 0.46 & 0.49 \\
\hline
\end{tabular}

Prior to acid treatment the clays were prtreated with $\mathrm{DCB}$ and $\mathrm{NaOH}$. The smectite was completely dissolved by the acid treatment, leaving feldspar as residue in the case of the coarse clay.Structural formulae (Table 4), calculated from the elements dissolved by $\mathrm{HCl}$ and $\mathrm{NaOH}$, suggest that the composition of the tetraoctahedral sheet was similar to that of the smectite in the soil samples. In general, the basalt smectite is richer in $\mathrm{Mg}$ and $\mathrm{Fe}$ but poorer in octahedral Al than the smectite in the soil samples (Curtin and Smillie, 1981; Freed and Peacor, 1989).Reports on the clay mineralogy of soils commonly assume that the soils and clay minerals are contemperanous. The clay mineralogy of the soils of the present study was affected by inherited smectite, probably of hydrothermal of deuteric origin. This mineral is unstable in the soil environment and, although its alteration products are fairly uniform in composition.

Conclusion: Smectite is unstable under the conditions prevailing in the soil. And substantial changes in its composition occur. $\mathrm{Mg}$ and Fe seem to be lost from the octahedral sheet during the weathering process, thereby reducing the octahedral cation occupancy from close to 3 , as in the smectite in clays is approximately 2.4 per $\mathrm{O}_{10}(\mathrm{OH})_{2}$, although the 060 spacing of $1.54 \AA$ indicates a retention of the trioctahedral structure. However, the XRD data gave an evidence of smectite. The results suggest the existence of smectites with octahedral cation occupancies intermediate between di - and trioctahedral minerals; such mineral were formed as weathering products of trioctahedral smectite.

\section{REFERENCES}

Alexiades, CA; Jackson, ML (1965). Quantitative determination of vermiculite in soils. Soil Sci. Soc. Amer. Proc. (29):522-527.

Brindley, GW (1961). Chlorite minerals: In: Brown, G (ed). The X-ray Identification and Crystal Structures of Clay Minerals. Min. Soc. London, p. 242-296.
Churchman, GJ (2000). The alteration and formation of soil minerals by weathering. In: Summer, ME (ed). Handbook of soil science, CRC Press New York, (1): 3-27.

Curtin, D (1979). A study of factors influencing the cation exchange properties of Irish soils: Unpublished Ph.D. Thesis, National University of Ireland, p.183.

Curtin, D; Smillie, GW (1981). Composition and Origin of smectite in soils Derived from Basalt in Northern Ireland. Clay and Clay Min., 29(4): 277284.

Dixon, JB; Jackson, ML (1959). Dissolution of interlayer from intergradient soil clays after preheating at $400^{\circ}$ C. Sci., (129):1616-1617.

Doust, H; Omatsola, E (1990). Niger Delta, in , Edwards, J. D., and Santogrossi, P.A., eds., Divergent/passive Margin Basins, AAPG Memoir, Tulsa, Ameri. Assoc. Petrol. Geol., (48): 239-248.

Ekweozor, CM; Gormly, JR (1983).Petroleum Geochemistry of Late Cretaceous and Early Tertiary Shales Penetrated by Akukwa. 2 Well in the Anambra Basin Southern Nigeria. J. Petrol. Geol., (6): 207-216.

Freed, RL; Peacor, DR (1989). Variability in Temperature of the Smectite/Illite Reaction in Gulf Coast Sediments. Clay Min., (24):171-180.

Frink, CR (1965).Characterization of Aluminum interlayers in soils clays: Soil Sci. Soc. Amer., Proc., (29):379-382

Genrich, DA; Bremner, JM (1972). A re-evaluation of the ultrasonic-vibration method of dispersing soils: Soil Sci. Soc. Amer., Proc., (36):944-947.

Grim, RE(1968). Clay Mineralogy: $2^{\text {nd }}$ ed., McGrawHill, New York, p. 439-440. 
Haack, RC; Sundaraman, P; Diedjomahor, JO; Xiao, H; Gant, NJ; May, ED; Kelsch, K (2000). The Niger Delta petroleum systems, Nigeria. In: Mello, MR; Katz, BJ (Eds). Petroleum Systems of South Atlantic Margins. Amer. Assoc. Petrol. Geol. Memoir, (73): 213-231.

Hashimoto, I; Jackson, ML (1960). Rapid dissolution of allophone and kaolinite-halloysite after dehydration: In:Ada, S (ed). $7^{\text {th }}$ National Conference, Washington D.C, 1958, Clays and Clay Min., Proc., Pergamon Press, New York, p. 102-113.

Jan, S; Norbert, C; Dennis, DDE (2002). Interpretation of $\mathrm{K}-\mathrm{Ar}$ dates of illitic clays from sedimentary rocks aided by modeling. Amer. Min., (87): 15281535 .

Keller, WD (1970). Environmental aspects of clay minerals. J. Sed. Petrol. Geol., 40(3): 39-46, 1970.

Kiely, PV; Jackson, ML (1965). Quartz, feldspar and mica dtermination for soils by sodium pyrosulphate fusion. Soil Sci. Soc. Amer., Proc., (29):159-163.

Kogbe,CA (1976). The Upper Cretaceous Abeokuta Formation of South Western Nigeria. Nigerian Field. p. 4.

Kulke H (1995). Regional Petroleum Geology of the World. Part II: Africa, America,Australia and Antarctica. In: Kulke, H (ed). Berlin, Gebrüder Borntraeger, p. 143-172

Mackenzeie, RC (1960). The evaluation of clay mineral composition with particular reference to smectite. Silicates Ind., (25):12-18.

Mamman, YD; Dike, EFC; Haruna,IV; Haruna, AI (2010). Clay mineralogy and paleodepositionalenvionments of late Cenomanian - Turonian sediments in the Yola arm, upper Benue trough, Northeastern Nigeria. $J$. Min. Geol., 46(1):1-12.

Marshall, CE (1949). The Colloid Chemistry of Silicate Minerals: Academic Press, New York, p. 56-66.

McAleese, DM (1954). Cationic exchange properties of some soils of North-East Ireland as affected by the nature of the clay and other soil fractions.
Unpublished Ph.D. Thesis, Queens University, Belfast, p. 248.

Mehra, OP; Jackson, ML (1960). Iron oxide removal from soils and clays by a dithionite-citrate system buffered with sodium bicarbonate: In:Ada $\mathrm{S}$ (ed). $7^{\text {th }}$ National Conference, Washington DC., 1958. Clay Min. Proc.,Pergamon Press, New York, p. 317-327.

Nwachukwu, SO (1972). The tectonic evolution of the Southern portion of the Benue trough, Nigeria. Geol. Mag., (109): 411- 419.

Obaje, NG; Wehner, H; Scheeder, G; Abubakar, MB ;Jauro, A (2004). Hydrocarbon prospectivity of Nigeria's inland basins: From the viewpoint of organic geochemistry and organic petrology. Amer. Assoc. Petrol. Geol. Bull., 88(3): 325-353.

Ojoh, K (1990). Cretaceous Geodynamic EEvolution of the Southern part of the Benue Trough (Nigeria) in the Eqitorial domain of the South Atlantic: Stratigraphic Basin analysis and paleogeography. Bull. centres Rech. Explor-Prod. Elf-Aquitaine, 14:419-442

Ojo, JO (1999). Depositional environments, palynological and organic geochemical studies of Gongola and Yola Basins, Nigeria: Implications for hydrocarbon potential". PhD Thesis, University of Ilorin, Nigeria, p. 355.

Olade, MA (1975). Evolution of Nigeria's Benue Trough (Aulocogen): A tectonic model". Geol. Mag., 112:575-583.

Omontese, OS; Imasuen, IO; Uzoegbu, MU (2019). Organic Geochemical Evaluation of Cretaceous Sediments from Asu River Group in the Afikpo Basin, Southeastern Nigeria. Int. J. Geol. Min., 5(2):269-274.

Onyeogu, T; Uzoegbu, MU; Ideozu, RU (2016).Clay Minerals Assessment from Maastrichtian Syclinal Afikpo, Nigeria. Int. J. Sci. Res. Publ., 6(9): 746 -753 .

Porrenga, DH (1967). Clay minerals and geochemistry of recent marine sediments in tropical areas an exemplified by Niger Delta, the Orinoco shelf and the shelf of Sarawak. Publiates Van het FysischGeografisch: Laboratorium Van de Universiteit Van Amsterdam, 9:7-23. 
Pruden ,G; King, HG/C (1969). A scheme of semimicro analysis for the major elements in clay minerals, based on modifications to conventional methods of silicate analysis: Clay Min., 8:1-13.

Rich, CI (1966). Concentration of dioctahedral mica and vermiculite using a fluoride solution. Clays and Clay Min., 14:91-98.

Ristori, GG; Cecconi, S; Vidrich, V; Pacifci, G (1974). Selective dissolution and structural formula detrivation of clay vermiculite from some Tuscan soils: Clay Min., 10:279-287.
Sawhney, BL; Jackson, ML (1958). Soil montmorilonite formulas. Soil Sci. Soc. Amer. Proc., 22:115-118.

Ugwueze, CU (2015). Integrated Study on Reservoir Quality and Heterogenity of Bonga Field, DeepOffshore Western Niger Delta. p. 49

Ukaegbu, VU; Akpabio, IO (2009). Geology and stratigraphy of middle Cretaceous sequences Northeast of Afikpo Basin, Lower Benue trough, Nigeria. Pacific J. Sci. Tech. 10(1):1-10. 